\title{
A study of brain regions associated with Core Skills of Gardner's Logical- Mathematical Intelligence using Functional Magnetic Resonance Imaging (Case Study)
}

\author{
Zohreh Yarmohamadi $^{1}$, Abolghasem Yaghoobi ${ }^{2}$, Khosro Rashid ${ }^{3}$, Rasol Kord Noghabi ${ }^{3}$ \\ 1-PhD Student, Department of Psychology, Bu-Ali-Sina University, Hamedan, Iran. \\ 2- Professor, Department of Psychology, Bu-Ali-Sina University, Hamedan, Iran (Corresponding Author). \\ E-mail: Yaghobi41@yahoo.com \\ 3- Associate Professor, Department of Psychology, Bu-Ali-Sina University, Hamedan, Iran.
}

Received: $14 / 11 / 2021$

Accepted: 04/01/2022

\begin{abstract}
Introduction: Logical-mathematical intelligence is one of the common needs of modern life to deal with various types of computational and problem-solving situations.

Aim: The aim of this study was to investigate the brain regions associated with the core skills of LMI (calculations, logical reasoning and game strategies) using functional magnetic resonance imaging (fMRI).

Method: This study used a cross- case design. From 28 male and female volunteers aged 18 years and over who visited the Brain Mapping Laboratory in 2020, one with very a high Logicalmathematical intelligence was selected through purposive sampling and using the Multiple Intelligence Developmental Assessment Scale (MIDAS). The tools used in this study were Computational Assignments, Chess and Logical Reasoning. FMRI was also utilized to examine the brain regions. Data were preprocessed and statistically analyzed in SPM-12.

Results: The results demonstrated similar neural activation involved in computational skills, logical reasoning, and chess game in the frontal and parietal lobes. They also showed significant activity in the cerebellum, insula, cingulate gyrus, precuneus, pre-and post-central gyri, fusiform gyrus, and supramarginal gyrus in all three skills.

Conclusion: The results revealed that the neural activation patterns in each skill have unique neural bases, but have common patterns with other skills of Logical-mathematical intelligence. These common and unique patterns present a unique neural architecture in support of the Theory of Multiple Intelligences as a scientific model of human intelligence.
\end{abstract}

Keywords: Logical reasoning, Game strategies, Magnetic resonance imaging, Calculations, Logical-mathematical intelligence

How to cite this article: Yarahmadi Z, Yaghoobi A, Rashid Kh, Kord Noghabi R. A study of brain regions associated with Core Skills of Gardner's Logical-Mathematical Intelligence using Functional Magnetic Resonance Imaging (Case Study). Shenakht Journal of Psychology and Psychiatry. 2022; 8 (6): 83-97 .URL: http://shenakht.muk.ac.ir/article-1-1332-en.pdf

Copyright $\odot 2018$ the Author (s). Published by Kurdistan University of Medical Sciences. This is an open access article distributed under the terms of the Creative Commons Attribution-Non Commercial License 4.0 (CCBY-NC), where it is permissible to download, share, remix, transform, and buildup the work provided it is properly cited. The work cannot be used commercially without permission from the journal. 


\title{
بررسى مناطق مغزى مرتبط با مهارتهاى اصلى هوش منطقى - رياضى كاردنر با استفاده از تصوير سازى تشديد مغناطيسى كار كردى (مطالعه موردى)
}

\author{
زهره يارمحمدى '، ابوالقاسم يعقوبى ‘' خسرو رشيد'، رسول كرد نوقابى \\ ا.دانشجوى د كتراى، گُروه روانشناسى، دانشگاه بوعلى سينا، همدان، ايران.
}

Y. استاد، گُروه روانشناسى، دانشگاه بوعلى سينا، همدان، ايران (مولف مسئول). ايميل: Yaghobi41@yahoo.com

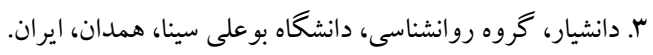

تاريخ بذيرش مقاله: |F./1F

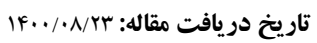

جكيله

مقدمه: هوش منطقى - رياضى از نيازهاى فراگير زندگى مدرن امروزى براى مقابله با انواع گوناگونى از موقعيتهاى محاسبهاى و حل مسئله به شمار مى آيد.

هدف: هدف از يزوهش حاضر بررسى مناطق مغزى مرتبط با مهارتهاى اصلى هوش منطقى - رياضى (محاسبات، استدلال منطقى و

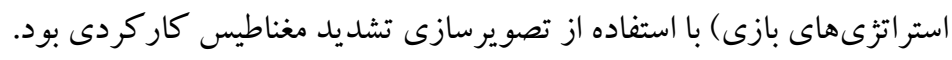

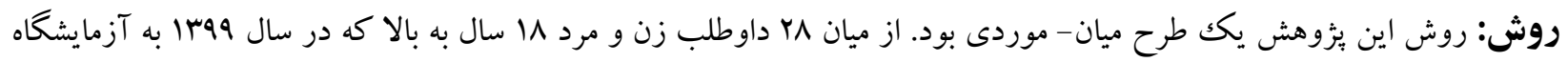

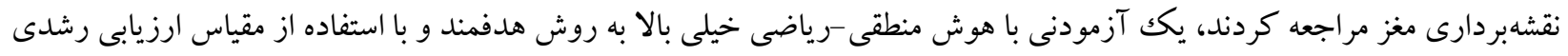

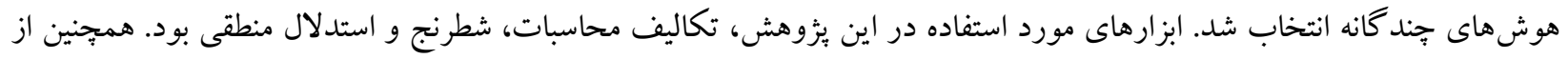

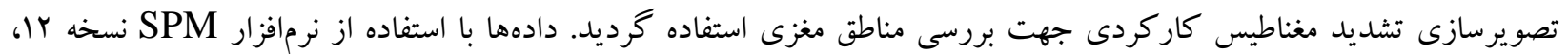
بيش يردازش و آناليز آمارى شدند.

يافته ها: يافتها، فعالسازى عصبى مشابهى را بين مهارتهاى محاسبات، استدلال منطقى و بازى شطرنج در مناطق بيشانى و آهيانهاى

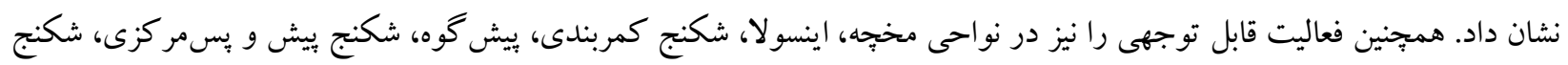

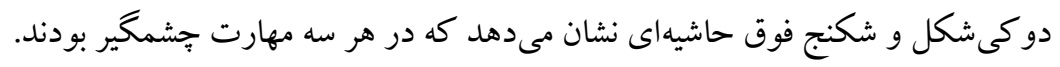

نتيجه كيرى: نتايج نشان داد كه الكوهاى فعالسازى عصبى در هر مهارت، داراى بايههاى عصبى منحصربهفردى بوده، با اين وجود با

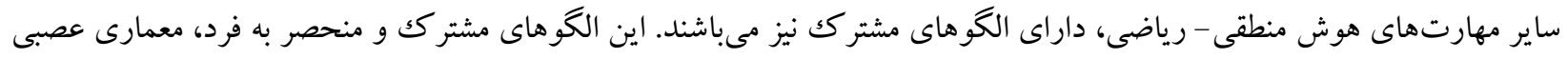

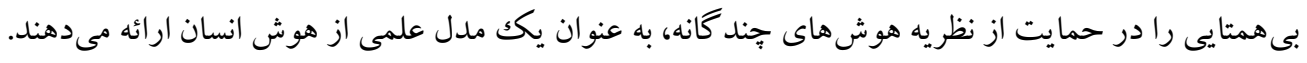
كليدوازهها: استدلال منطقى، استراتزىهاى بازى، تصوير سازى تشديد مغناطيسى، محاسبات، هوش منطقى -رياضى 
كارانيان؛، IV) (Y)؛ اما مطالعات اندكى صورت گرفته

مقدمه

(9 (مطالعه) فقط جنبه محاسباتى اين هوش را مد نظر قرار دادهاند و كمتر مطالعهاى به بررسى عصب شناختى اين هوش براساس مهارتهاى اصلى آن برداخته است و ولى بـ مطالعات انجام شده به صورت بر اكنده و نه تحت عنوان هوش منطقى - رياضى صورت گرفته است. براى مثال مطالعات بررسى شده در مورد محاسبات (جهار عمل اصلى حساب شامل جمع، تفريق، ضرب و تقسيم) نشان

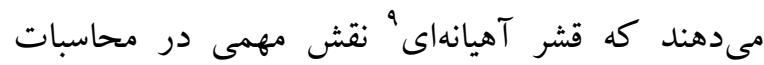
دارد، اخرجهه فعاليت قسمتهاى بيشانى "مغز نيز به وفور در هنگام محاسبات مشاهده مىشود؛ اما اينها مربوط به موارد كلى نظير حافظه فعال، توجه و فر آيندهاى عصب شناختى در زمينه محاسبه است (انصارى")

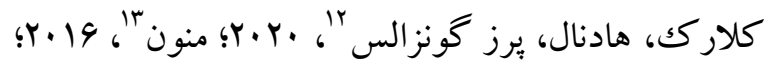
يترز و دىاسميت

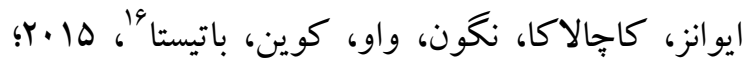

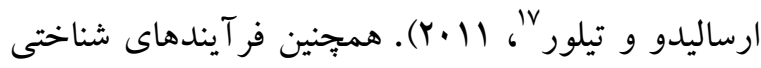
دركير در اشكالى از بازىهاى فيزيكى كه از منابع ذهنى

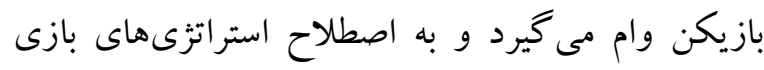
ناميده مىشود، مدتهاست ذهن روانشناسان را به خود مشغول كرده است. بازى شطرنج ^ا ازجمله اين بازىها است و مطالعات كم استم

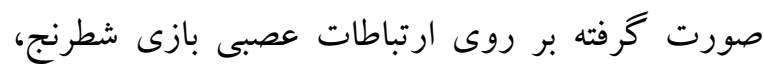

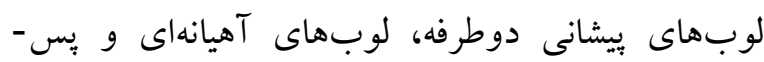

8- Karanian

9- Parietal cortex

${ }^{10}$ - Frontal

${ }^{11}$ - Ansari

${ }^{12}$ - Clark, Hudnall, Hudnall \& Perez-Gonzalez

${ }^{13}$ - Menon

14- Peters \& De Smedt

${ }^{15}$ - Cragg \& Gilmore

${ }^{16}$ - Evans, Kochalka, Ngoon, Wu, Qin, Battista \& Menon

${ }^{17}$ - Arsalidou \& Taylor

${ }^{18}$ - Chess

يكى از نيازهاى فراگير زندگى مدرن امروزى كه ابزار

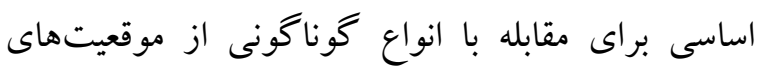
محاسبهاى و حل مسئله به شمار مى آيد و در همه رشتههاى علمى مدرن با اهميت در نظر گرفته مىشود،

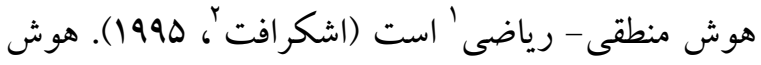
منطقى - رياضى از اشكال متمايز هوشىهاى هند است كه در سال س1911 توسط كاردنر منتشر و يكى از اولين صورتبندىها در مورد هوش است كه براساس

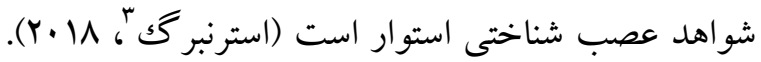
بر اين اساس دركك اين مهارت ذهنى هدفى مهم براى علوم عصب شناختى به حساب مى آيد. هوش منطقى - رياضى به صورت توانيى انجام زنجيرهاى از استدلالها و تشخيص الكوها و قواعد در دنياى بيرامون تعريف مىشود (رشيد، IM IV) و شواهد عصب شناختى اين هوش كه از سال س1911 بهروزرسانى نشده شامل،

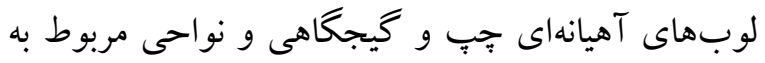

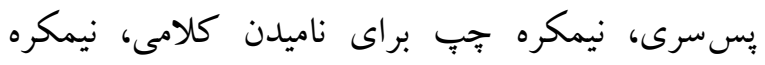
راست براى سازماندهى فضايى، سيستم بيشانى براى برنامهريزى و تنظيم هدف است (شيررّ، 19. (Y). با اين حال نتايج حاصل از بررسى بر روى واحدهاى مختلف شناختى يا مهارتهاى خاص مرتبط با اين هوش نشان داد كه علاوه بر محاسباته و حل مسئله به روش

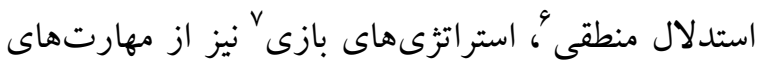
اصلى هوش منطقى - رياضى به شمار مى آيد (شيرر و

\footnotetext{
1- Logical-mathematical intelligence

2- Ashcraft

3 - Sternberg

4- Shearer

5 - Calculations

6. Logical reasoning

7. Game strategies
} 
اين سؤال ياسخ دهد كه آيا افراد داراى هوش منطقى رياضى خيلى بالا، فعاليت قابل ملاحظهاى را در ساختارهاى مغزى ادعا شده توسط كاردنر نشان مى نىهند

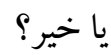
روش

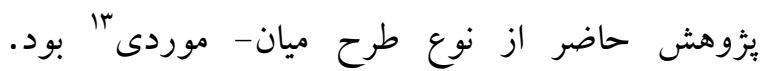
شركت كنند گان مطالعه حاضر را افراد \1 سال به بالاى مر اجعه كننده به آزمايشگاه نقشهبردارى مغز در سال هوسا تشكيل داده كه از بين آنها ا آزمودنى به روش هدفمند انتخاب شد. از جمله معيارهاى ورود به تحقيق شامل تشخيص هوش منطقى - رياضى خيلى بالا توسط مقياس

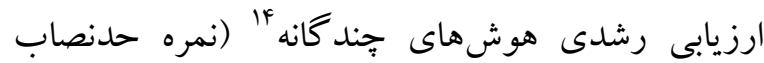

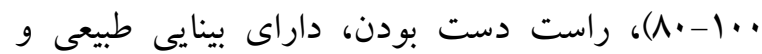
بلدون سابقه بيمارى عصبى و قرار نداشتن هيجِكونه فلزى در بدن افراد بود و همجنين معيار خروج از تحقيق نيز شامل بىقرارى و تكانهاى زياد سر در حين انجام تكاليف در اسكنر و عدم توانايى در به اتمام رساندن تكاليف در اسكنر بود. شركت در اين آزمايش كاملاً داوطلبانه بود و به آزمودنى اين اطمينان داده شد كه هر زمان كه مايل باشد مىتواند از فرآيند آزمايش خارج شود. رضايت كتبى از آزمودنى جهت شركت در اين آزمايش كسب شد. شيوه اجراى اين آزمايش به اين صورت بود كه آزمودنى سه تكليف آزمايشى را در اسكنر به بايان رساند: تكليف محاسبات، تكليف استدلال منطقى و تكليف بازى شطرنج. محر ككهاى تكاليف همه بهال

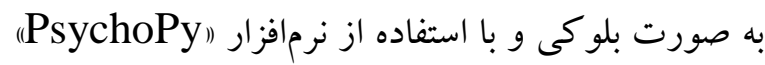
ارائه شدند. براى تكليف محاسبه جهار عمل اصلى (جمع،

${ }^{13}$ - Cross-Case

${ }^{14}$ - Multiple intelligences developmental assessment scales
سرى' را به عنوان مناطق مرتبط با بازى شطرنج معرفى

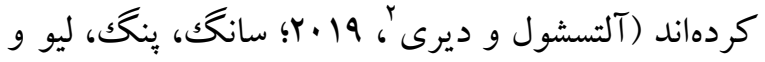

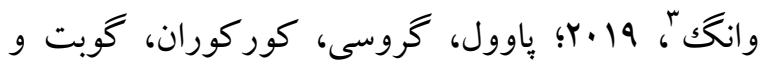

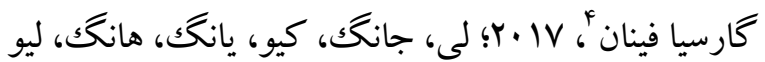

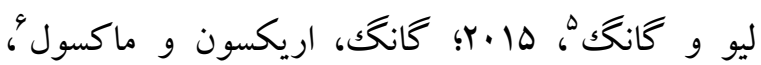
ها1Y). بعلاوه مطالعات اندكى تصويربردارى مغز در ارتباط با توانايى حل مسئله به روش استدلال منطقى كه با

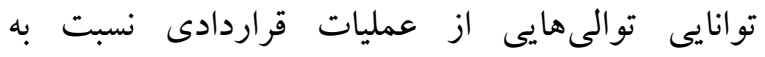
نمايشهاى ييجيده تعريف مىشود، بر مشاركت مناطق توزيع شده بيش بيشانى و آهيانهاى تأكيد داشتهاند (برادو

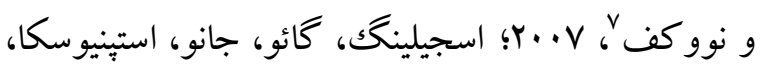

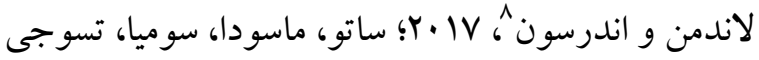

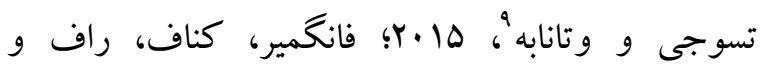

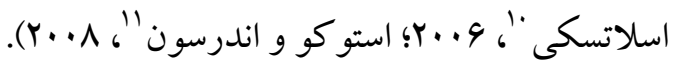
با اين حال تفاسير بدست آمده از عصب شناختى هوش منطقى - رياضى همواره با انتقاداتى رو به رو بوده كه مهمترين آن اين است كه فاقد شواهد آزمايشى قابل اعتبار در زمينه عصب شناختى است و از آنجايى كه اين نظريه در بين روانسنجها اعتبار جندانى ندارد، تكرار آزمايشها و تأييد شواهد روانشناختى و تجربى به اثبات وجود جنين هوشى و مبناى عصب شناختى اين نظريه

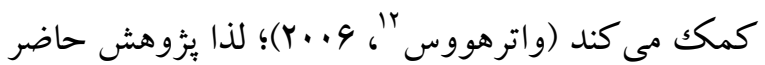
قصد دارد از طريق مطالعه مستقيم هوش منطقى - رياضى با بررسى عصب شناختى مهارتهاى اصلى اين هوش به

\footnotetext{
- Occipital

${ }^{2}$ - Altschul \& Deary

3 - Song, Peng, Liu \& Wang

4- Powell, Grossi, Corcoran \& Garcia Finana

5 - Li, Jiang, Qiu, Yang, Huang, Lui \& Gong

6- Gong, Ericsson \& Moxley

7. Prado \& Noveck

${ }^{8}$ - Schilling, Gao, Janve, Stepniewska, Landman \& Anderson

- Sato, Masuda, Someya, Tsujii \& Watanabe

${ }^{10}$ - Fangmeier, Knauff, Ruff \& Sloutsky

${ }^{11}$ - Stocco A \& Anderson

${ }^{12}$ - Waterhouse
} 
جرخش •Q درجه، ماتريس

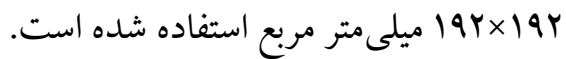
دادهها با استفاده از نرمافزار SPM نسخه بارك TOOL BOX منظور بيش بيردازش و آناليز آمارى دادهها، تحليل شدند.

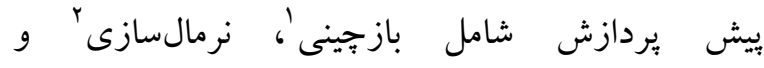
هموارسازى ّاست كه يردازش اصلى دادهها بر روى خروجى هموارسازى صورت مى گيرد. .براى ديدن TOOL يكاوير عملكردى نيز از xjview، BOX مبتنى بر MATLAB

ابزار تكاليف تصويرسازى تشديد مغناطيس كاركردى!! براى بررسى عصب شناختى هوش منطقى - رياضى ما سه مهارت اصلى اين هوش را انتخاب و براساس آن تكاليف طراحى شد. اين سه مهارت شامل محاسبات (استفاده مؤثر از حساب در زندكى روزمره براساس \& عمل اصلى رياضى)، استدلال منطقى (توانايى استفاده از استدلال منطقى در حل مشكلات روزانه) و استراتزىهاى بازى

$$
\text { (مهارت و فن خوب در بازى) بود. }
$$

تكليف محاسبات ؛ اين تكليف شامل .19 مسئله محاسباتى محاسباتى از هر جهار عمليات اصلى در رياضى بود. اين تكليف بركرفته از روشى كه انصارى، رابنر، كسجاتينگك، ريشوفر و ابنر (11 (Y) استفاده كردند، يياده يياده شد. در مسائل مربوط به محاسبات، اعداد صحيح بين Y تا و استفاده شد. مسائل مربوط به محاسبات به

1- Realignment

2- Normalization

3- Smoothing

4- Functional magnetic resonance imaging

5 - Calculations task

6- Ansari, Grabner, Koschutnig, Reishofer \& Ebner
ضرب، تقسيم و تفريق) رياضى را در هشت بلو كك به

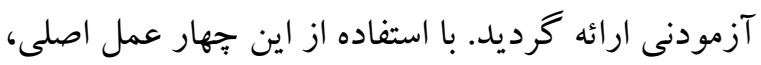
ابتدا مسائل عددى نمايش و سيس دو جواب در زير مسئله نمايش داده شد و از آزمودنى خواسته مى شد تا جواب درست را انتخاب كند. در تكليف استدلال منطقى نيز، ابتدا عبارت استدلالى و سبس نتيجه گيرى آن ارائه و آزمودنى در مورد درستى عبارت نتيجه گيرى، قضاوت كرد. در بايان تكليف شطرنج شامل نوارى از تصاوير

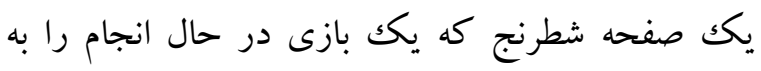

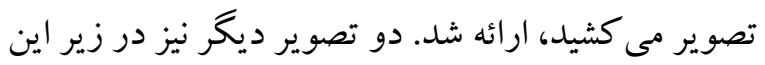
تصاوير به آزمودنى نشان داده شد و از او خواستيم تصميم بحيرد كه كدام يكك از دو حركت به تصوير كشيده شده، حركت بعدى در بازى شطرنج است. براى به حداقل رساندن حركات، سر آزمودنى با استفاده از كوسنهايى تثبيت شد. براى باسخ دادن، به ترتيب دو شاسى پِاسخ در دست جِ و وراست آزمودنى قرار داده

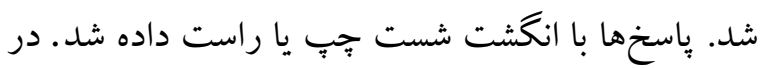
هر شرايط، آزمودنى كليد سمت جِّ را براى جواب

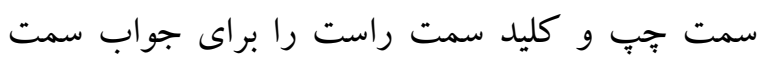
راست فشار داد. تصاوير MR با استفاده از اسكنر ب تسلا زيمنس با يك سرييج ^ كانال بدست آمد. تصاوير

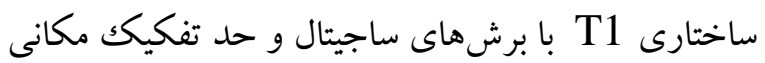
بالا با ضخامت برش 1 ميلىمتر، تعداد كل برشها بارئا برابر

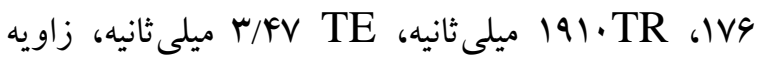

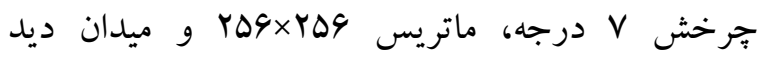


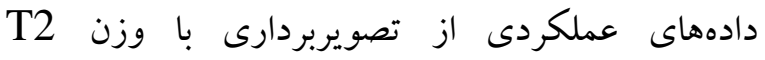
برشهاى اكسيال با ضخامت r ميلىمتر، تعداد كل

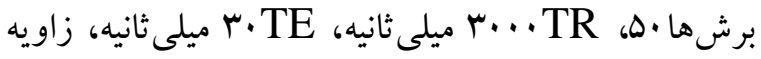


(به عنوان مثال براى تأييد قانون اكر H باشد، آنكاه مربع وجود دارد، آيتم هدف به صورت H Hرون مربع ظاهر مىشود). در شرايط ا-عدم تطابق، فقط يك اصل در آند قانون و آيتم هدف وجود داشت (به عنوان مثال براى تأييد قانون اخر J نباشد، آنگاه مربع وجود دارد دارد، آيتم هدف به صورت H درون مربع ظاهر مىشود). در شرايط r-عدم تطابق، آيتم تصويرى با حرف و شكل ذكر شده در قانون مطابقت ندارد (به عنوان مثال براى تأييد قانون

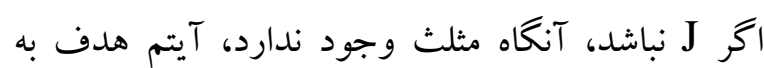
صورت H درون مربع ظاهر مى شود. تهار قانون در اين بارادايم استفاده شد (وجود يا عدم وجود نفى در قسمت هرت ييشين قاعده و وجود يا عدم وجود نفى در قسمت نتيجه قاعده).

در كل مثبت بود (به عنوان مثال اكر HA باشد ، آنكاه

$$
\text { دايره وجود دارد) }
$$

AN در قسمت نتيجه قاعده نفى ارائه مىشود (به عنوان

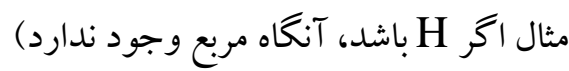

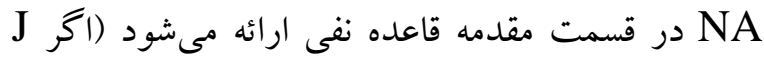
وجود نباشد، آنظاه دايره وجود دارد)

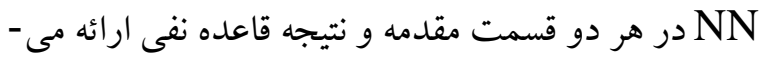

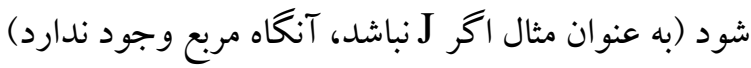
آيتمهاى هدف از يكى از شش حرف ارائه شده به

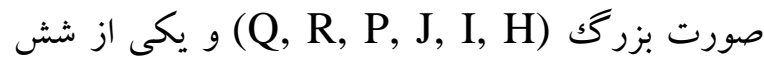

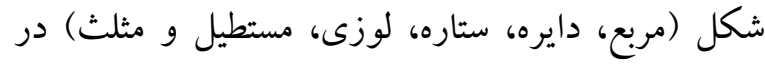
مركز يكك ميدان ديدارى تشكيل شد. هر آزمايش با ارائه يكك علامت ثابت ديدارى در مركز

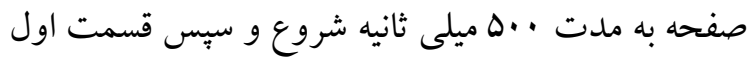

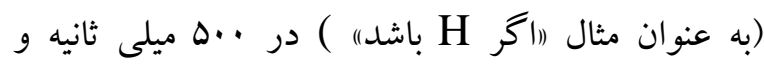
قسمت دوم (آنكاه مربع وجود دارده)) در ل.10 ميلى

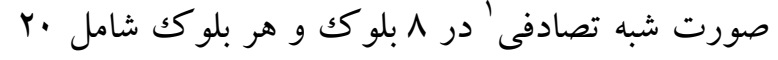
سؤال ارائه شد. هر مسئله به مدت ب بثانيه و به دنبال آن جواب صحيح (راهحل) و يكك جواب انحرافى براى r آنائ

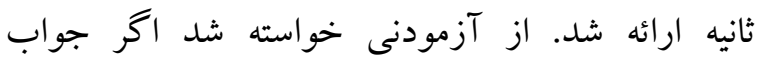
صحيح، سمت راست قرار دارد، دكمه سمت راست و و اخر جواب صحيح، سمت جِّ قرار دارد، دكمه سمت جִب را فشار دهد. در نيمى از مسائل، جواب صحيح در

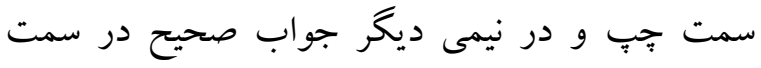
راست ارائه شد تا از هرگونه حدسى جلو گيرى شود.

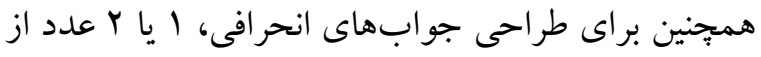

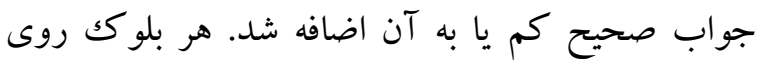

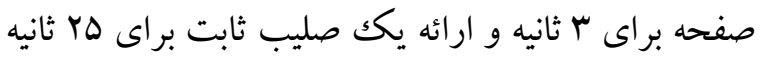
آغاز گرديد. يكك دوره صليب ثابت در بايان هر بلو كى برك

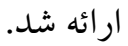

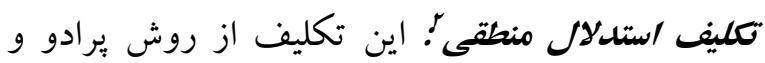
نوو كف (Y.V) الكوبردارى شده است. هر آزمايش

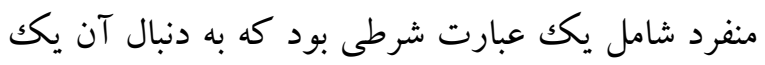
آيتم تصويرى ارائه مىشد. قاعده شرطى رابطه حرف و

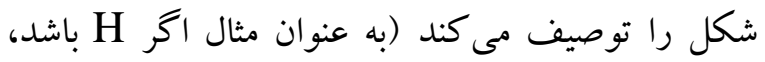
آنكاه مربع وجود دارد) و آيتم هدف بر براساس تركيب حرف و شكل به صورت تصوير درمى آمد، به عنوان

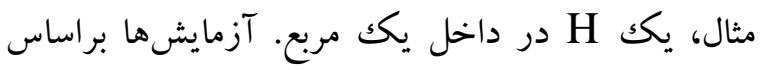
تعداد عناصر نامتناسب بين قاعده شرطى و آيتم هدف تهيه شد. از اينرو، آزمايشها به سه شرط مختلف، .عدم تطابق (يعنى تطابق كامل)، ا- عدم تطابق (عدم تطابق متوسط) و r - عدم تطابق (عدم تطابق كامل) تقسيم شدند. در شرايط ·- عدم تطابق، آيتم تصويرى

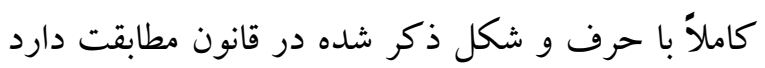

\footnotetext{
1- Pseudo-randomized

${ }^{2}$ - Logical reasoning task
} 
با رنگك زرد نشان داده شد تا با زرد ارائه شده در شرايط تكليف شطرنج، مطابقت داشته باشد. مهرههاى شطرنج نيز به طور تصادفى روى صفحه جيده مىشوند تا از حركتهاى احتمالى شر كت كننده جلو گيرى شود. در مجموع از دوازده سناريو مختلف در هر شرايط استفاده شد. هر بلوكك شامل سه سناريو مختلف بود كه در نتيجه جهار بلوكك ايجاد شد. هر بلوكى با ارائه يكك سؤال كوتاه درباره معرفى بلوكك به مدت 4 ثانيه، براى آزمودنى آغاز شد. بلوكك از دو بازى مختلف تشكيل شده است. نوار به به بـ بـ تصوير كشيدن بازى با مهره در حال انجام در نيمه بالاى صفحه به مدت Y I ثانيه و سبس دو تصوير كه نتايج ممكن اين سناريو است براى rا ثانيه ديخر در نيمه يايين صفحه نمايش داده شد.

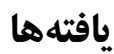
نتايج مربوط به ويز گیى هاى دمو گرافيك شركت كنند كان

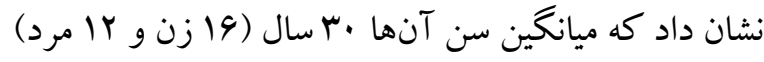
و در نهايت آزمودنى اي با سب سال سن و كسب نمره در مقياس ارزيابى رشدى هوش هاى جند گُانه براى انجام آزمايش انتخاب شد. مناطق فعال شده حين تكاليف جمع و تفريق در جدول ا ارائه شده است. اين جدول شامل مختصات نواحى فعال شده و همجِنين ميزان فعاليت هر منطقه رادر يكى از دو نيمكره نشان مىدهد.
ثانيه ظاهر مىشود. بعد كل قانون براى .... ميلى ثانيه بر روى صفحه باقى مىماند تا زمانى كه آزمودنى يكى از دو دكمه را فشار دهد (ياسخ بله / خير). تكليف بازى شطرنج: اين تكليف بركرفته از روش باول و و همكاران (Y.IV) است. در كار آزمايشى (ابازى شطرنج))، آزمودنى بايد تصميم بـيرد ("جه حر كتى انجام

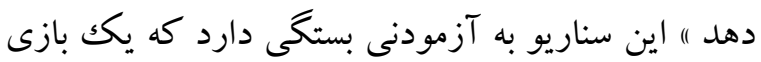

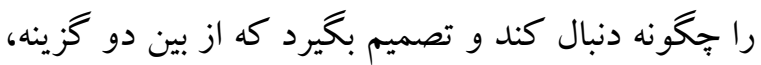
كدام حركت را انتخاب كند. بازىهاى شطرنج به طور تصادفى از يايگاه داده بازىهاى قبلى استادان شطرنج/ استادان بزرگك (http://www.chess.com/games/) با نقطه شروع تصادفى از بازى انتخاب شد. آزمودنى بايد

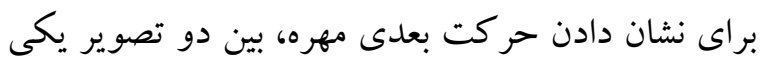
را انتخاب كند. يكك تصوير حر كتى است كه استاد / استاد بزرگك شطرنج در طول بازى شطرنج انجام داده است (ياسخ صحيح) و تصوير دوم، حركتى متفاوت از مهره شطرنج (ياسخ نادرست) است. در شرايط كنترل آزمودنى

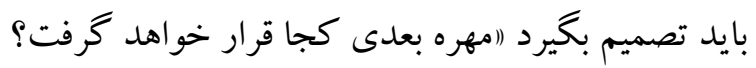
"به آزمودنى آموزش داده مىشود كه فقط يك قانون در سناريوى مهره وجود دارد و آن اين است كه مهره فقط مى تواند از يكك طرف تخته به طرف مخالف حركت كند، يعنى يا از جِّب به راست يا از بالا به هيايين است؛ اما

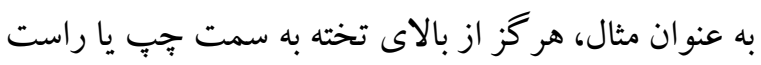
يا از سمت راست تخته به بالا يا بايين تخته نمىرود .مهره

جدول 1 مشخصات مناطق فعال شده براى تكاليف جمع و تفريق

\begin{tabular}{|c|c|c|c|c|c|c|c|c|c|c|c|}
\hline \multicolumn{6}{|c|}{ مشخصات مناطق فعال شده براى تفريق } & \multicolumn{6}{|c|}{ مشخصات مناطق فعال شده براى جمع } \\
\hline $\mathbf{K}$ & $\mathbf{X}$ & $\mathbf{Y}$ & $\mathbf{Z}$ & نواحى مغزى & نيمكره & $\mathbf{K}$ & $\mathbf{X}$ & $\mathbf{Y}$ & $\mathbf{Z}$ & نواحى مغزى & 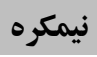 \\
\hline rvif & $-{ }_{Y F}$ & $-\Delta \varphi$ & 4. & مخجهם & קֶֶ & qrr. & -1 & $-i \wedge$ & -11 & مخجه & ب \\
\hline 19. & $-Y F$ & $-\Delta \varphi$ & 9. & شكنج كمربندى & 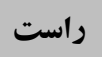 & rq. & Ir & $-f$ & $\Delta \cdot$ & شكنج كمربندى & 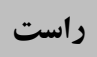 \\
\hline Fa.r & $-Y F$ & $-\Delta 9$ & 4. & مخجه & 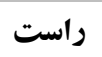 & $\wedge \Delta \vee 1$ & YF & $-r q$ & $-r$ & مخجهه & راست \\
\hline
\end{tabular}




\begin{tabular}{|c|c|c|c|c|c|c|c|c|c|c|c|}
\hline$\Delta F \Lambda$ & -9 & $-1 f$ & rr & شكنج بِ مركزى & جֶ & Wq & Ir & $-f$ & $\Delta$. & شكنج ييشانى ميانى & راست \\
\hline$V \Delta$ & $r$. & 1. & 1. & اينسولا & راست & $r v$. & ir & $-f$ & $\Delta \cdot$ & اينسولا & راست \\
\hline 194 & $-Y F$ & $-\Delta 9$ & 4. & اينسولا & جֶ & $\wedge$. & ir & $-f$ & $\Delta$ & اينسولا & جب \\
\hline$\Delta \mu q$ & $-Y F$ & $-\Delta 9$ & 4. & زيرشكنج & راست & $1 \cdots 1$ & ir & $-f$ & $\Delta \cdot$ & زيرشكنج & جֶ \\
\hline gF & 1. & YF & YF & كمربند قدامى & راست & qv & $\wedge$ & YF & re & كمربند قدامى & راست \\
\hline IrA & $-\Delta r$ & -1 & Ma & شكنج ييشمركزى & جֶ & m & -4 & ir & YA & كمربند قدامى & جֶ! \\
\hline MIF & $-Y F$ & $-\Delta \varphi$ & 9. & شكنج ييشانى ميانى & 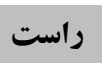 & VA & & f. & YF & شكنج ييشانى ميانى & جֶ \\
\hline 91. & $-Y F$ & $-\Delta 9$ & 4. & شكنج بيشانى ميانى & جֶ & $9 \times 1$ & Ir & $-F$ & $\Delta$. & شكنج ييشانى ميانى & راست \\
\hline YFD & $-Y F$ & $-\Delta \varphi$ & 4. & شكنج بيش مركزى & راست & MTFT & Ir & $-F$ & $\Delta$. & شكنج بيشمركزى & راست \\
\hline$r \cdot \Delta$ & $-\Delta F$ & $\wedge$ & YF & شكنج بيشانى تحتانى & جֶ" & $r \cdot \mu \wedge$ & Ir & $-f$ & $\Delta \cdot$ & شكنج پِ مركزى & راست \\
\hline MA & $-Y F$ & $-\Delta \varphi$ & 4. & شكنج ييشانى فوقانى & راست & FqF & Ir & $-F$ & $\Delta \cdot$ & شكنج ييشانى تحتانى & راست \\
\hline$k \cdot \Lambda$ & $-Y F_{-}$ & $-\Delta \varphi$ & 4. & لوبول آهيانه فوقانى & راست & kq. & Ir & $-F$ & $\Delta$. & شكنج ييشانىفوقانى & راست \\
\hline 110 & $-T^{F}$ & $-\Delta \varphi$ & 4. & لوبول آهيانه تحتانى & راست & frq & Ir & $-F$ & $\Delta$. & لوبول آهيانه فوقانى & راست \\
\hline YF. & $-Y F$ & $-\Delta 9$ & 9. & بيش گوه & راست & rar & Ir & $-F$ & $\Delta \cdot$ & لوبول آهيانه تحتانى & راست \\
\hline$r . q$ & $-{ }^{F}$ & $-\Delta q$ & 9. & بيش كوه جِب & جֶ & $\Delta \wedge q$ & Ir & $-F$ & $\Delta$. & بيش كوه & راست \\
\hline$\Delta q$ & $-Y F$ & $-\Delta 9$ & 4. & فوقحاشيهاى & 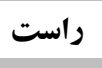 & TYO & Ir & $-F$ & $\Delta$. & ييش گوه & جֶ \\
\hline$\Lambda \mathrm{V}$ & $-Y^{F}$ & $-\Delta \varphi$ & 9. & فوق حاشيهاى & جֶ & rov & Ir & $-F$ & $\Delta$. & فوق حاشيهاى & جֶ \\
\hline $\mid r \wedge$ & $\wedge$ & -11 & $r$ & تالاموس & راست & ror & Ir & $-f$ & $\Delta$. & فوق حاشيهاى & راست \\
\hline rrו & $-{ }^{\prime} F$ & $-\Delta 9$ & 9. & بيشانى تحتانى & هب & 191 & Ir & $-F$ & $\Delta$. & تالاموس & راست \\
\hline$\Delta V \Delta$ & $-Y F$ & $-\Delta \varphi$ & 4. & آهيانه فوقانى & راست & FF & Ir & $-F$ & $\Delta$. & زبانى & ج" \\
\hline Iro & $-Y F$ & $-\Delta \varphi$ & 9. & بيشانى فوقانى & راست & Yla & -9. & -94 & $\wedge$ & گيجگاهى فوقانى & جֶ \\
\hline TAY & $-Y F$ & $-\Delta 9$ & 4. & بيشانى فوقانى & جֶ & rVA & Ir & $-F$ & $\Delta \cdot$ & بيشانى فوقانى & راست \\
\hline $11 r$ & $\Delta$. & $-r$. & $\wedge$ & شكنج گيجگاهى فوقانى & راست & ror & Ir & $-F$ & $\Delta \cdot$ & ي بيشانى فوقانى & جِ \\
\hline$\Delta q$ & $-Y F$ & $-\Delta \varphi$ & 4. & لوبول آهيانه تحتانى & جֶ? & f. & Ir & $-F$ & $\Delta \cdot$ & دو كى شكل & راست \\
\hline$\Delta q \mu$ & $-Y F$ & $-\Delta 9$ & 9. & آهيانه فوقانى & جֶ & & & & & & \\
\hline
\end{tabular}

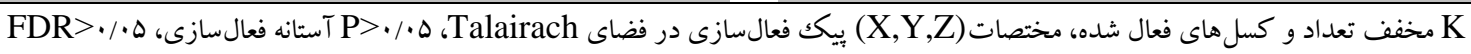

آهيانهاى، بيشانى و مناطق بيش بيشانى را فعال ساخت.

علاوه بر اين با فعاليتى در اينسولاى دوطرفه، مخجهه و

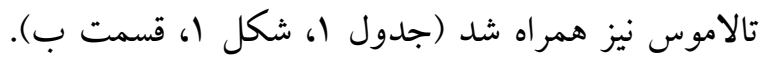

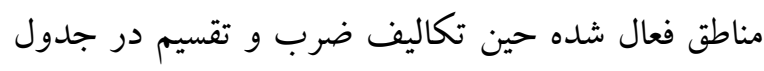
r ارائه شده است. اين جدول نيز شامل مختصات نواحى نالي

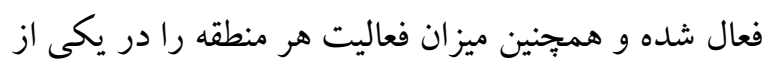
دو نيمكره نشان مىدهد.
يافتهاى حاصل از بردازش دادهها براى تكاليف جمع و

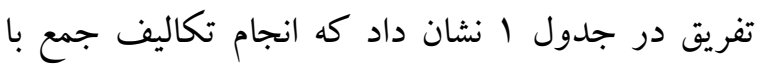

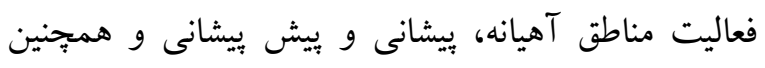

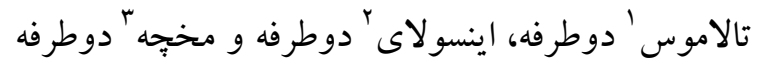

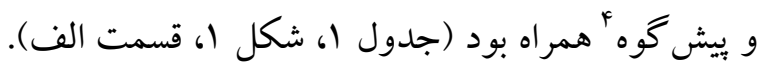

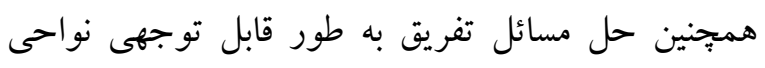


جدول r مشخصات مناطق فعال شده براى تكاليف ضرب و تقسيم

\begin{tabular}{|c|c|c|c|c|c|}
\hline \multicolumn{6}{|c|}{ مشخصات مناطق فعال شده براى تقسيم } \\
\hline $\mathbf{K}$ & $\mathbf{X}$ & $\mathbf{Y}$ & $\mathbf{Z}$ & نواحى مغزى & 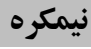 \\
\hline $19 \cdot \mathrm{V}$ & -49 & $-r F$ & 94 & مخجه & جֶب \\
\hline qv & -48 & $-r F$ & ar & شكنج كمربندى & جب \\
\hline$r \cdot r$ & $-r q$ & $-r F$ & 94 & مخجهים & 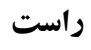 \\
\hline 949 & -48 & $-r F$ & ar & شكنج ״س مركزى & جֶ! \\
\hline $1 \wedge \Delta$ & $-r q$ & $-r \psi$ & 94 & شكنج بيشانى ميانى & 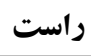 \\
\hline ir & $-r q$ & $-r F$ & 94 & 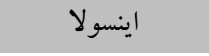 & جب \\
\hline $10 r$ & $-r$. & 9 & $-\varphi$. & زيرشنج & 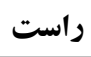 \\
\hline$r \Delta \Delta$ & $-r q$ & $-r F$ & ar & آهيانه فوقانى & جִب \\
\hline req & $-r q$ & $-r q$ & 94 & شكنج ييشمركزى & جب \\
\hline IV & $-r 4$ & $-\mu F$ & $G Y$ & بيشانى فوقانى & 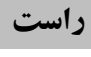 \\
\hline$\wedge \cdot$ & $-r q$ & $-r \mu$ & $G Y$ & شكنج ييشانى ميانى & جִب \\
\hline ivr & $r$. & $-r 9$ & 91 & شكنج ييش مركزى & راست \\
\hline 9 & $-r q$ & $-r F$ & ar & شكنج بس مر كزى & راست \\
\hline 110 & -49 & $-r F$ & ar & شكنج ييشانى فوقانى & راست \\
\hline$\Delta r$ & $-r q$ & $-r q$ & 94 & لوبول آهيانه فوقانى & راست \\
\hline$\Delta q$ & $-r q$ & $-r F$ & ar & بيش كوه & جب \\
\hline 110 & $-r q$ & $-r F$ & 94 & ي ييشانى فوقانى & جִب \\
\hline$\wedge$ & $-r q$ & $-r F$ & ar & فوق حاشيهاى & جب \\
\hline
\end{tabular}

مشخصات مناطق فعال شده براى ضرب

\begin{tabular}{|c|c|c|c|c|c|}
\hline $\mathbf{K}$ & $\mathbf{X}$ & $\mathbf{Y}$ & $\mathbf{Z}$ & نواحى مغزى & نيمكره \\
\hline rYAQ & -11 & $-r$. & v9 & مخخجه & جب \\
\hline 1. & -11 & $-r$. & $-r$. & شكنج كمربندى & راست \\
\hline rFaF & -11 & $-r$. & $-r$. & مخحِه & راست \\
\hline Fi & -11 & $-r$. & $-r$. & شكنج ييشانى ميانى & راست \\
\hline$r$. & -11 & $-r$. & $-r$. & اينسولا & راست \\
\hline w & -11 & $-r$. & $-r$. & شكنج يس مركزى & راست \\
\hline FVY & $-r \cdot$ & $r$ & r. & زيرشكنج & جب \\
\hline qV & 1. & rF & rF & كمربند قدامى & جب \\
\hline $1 \cdot 1 \Delta$ & -11 & $-r$. & $-r$. & شكنج بيشر كزى & جب \\
\hline $9 M 1$ & -11 & $-r$. & $-r$. & شكنج يشانى ميانى & جُ \\
\hline 11 & -11 & $-r$. & $-r$. & شكنج ييشانى ميانى & راست \\
\hline$\Delta r I$ & Fr & -11 & rᄉ & شكنج يش مركزى & راست \\
\hline (r) & -9. & $-1 f$ & rr & شكنج يسمر كزى & جب \\
\hline rr & -11 & $-r$. & $-r$. & شكنج ييشانى تحتانى & جب \\
\hline$r \cdot v$ & -11 & $-r$. & $-r$. & شكنج بيشانى فوقانى & جب \\
\hline rrr & -11 & $-r$. & $-r$. & لوبول آهيانه فوقانى & هب \\
\hline $\mathrm{kr}$ & -11 & $-r$. & $-r$. & لوبول آهيانه تحتانى & جب \\
\hline IVa & -11 & $-r$. & $-r$. & ي يش كوه & راست \\
\hline $19 V$ & -11 & $-r$. & $-r \cdot$ & بيش گوه & جب \\
\hline VY & -11 & $-r$. & $-r$. & فوق حاشيهاى & جب \\
\hline iv & -11 & $-r$. & $-r$. & فوق حاشيهاى & راست \\
\hline 99 & $\wedge$ & -11 & r & تالاموس & راست \\
\hline rmo & $-1 f$ & $-r 9$ & Fq & شكنج كمربندى & جب \\
\hline il & -11 & $-r$. & $-r$. & شكنجزبانى & קֶ \\
\hline int & $\Delta r$ & -11 & F & شكنج گيجكاهى فوقانى & جٍ \\
\hline$r \cdot V$ & -11 & $-r$. & $-r$. & ي يشانى فوقانى & جֶ \\
\hline f. & -11 & $-r$. & $-r$. & ي يشانى فوقانى & راست \\
\hline FA. & -11 & $-r$. & $-r$. & آهيانه فوقانى & جب \\
\hline MFY & -11 & $-r$. & $-r$. & آهيانه فوقانى & راست \\
\hline
\end{tabular}

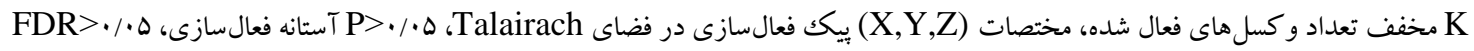

با فعاليتى در مخجه دوطرفه و بيش گوه نيز همراه بود

(جدول r ب، شكل (، قسمت ج) و مسائل تقسيم نيز فعاليت

قابل توجهى را در مناطق آهيانه، بيشانى و مخجه دوطرفه
مسائل مربوط به ضرب با فعاليت در مناطق گيجگاهى'؛ ييشانى و ييش بيشانى و آهيانهاى همراه بود. علاوه بر اين

1- Temporal 
فوقانى و تحتانى، مخجهه، اينسولا، شكنج ييش و پِّ مركزى، شكنج كمربندى، بيش گوه و فوق حاشيهاى مشاهده كرد. مناطق فعال شده حين تكاليف استدلال منطقى و بازى شطرنج در جدول ب ارائه شده است. اين جدول نيز مانند جداول ا و r، مختصات نواحى فعال شده و فعاليت هر منطقه را در يكى از دو نيمكره ارائه مىدهد.
نشان دادند (جدول Y، شكل (، قسمت د). با توجه به مناطق بدست آمده از تكاليف جمع، تفريق، ضرب و تقسيم مىتوان انتظار داشت، هنگام انجام محاسبات مناطق

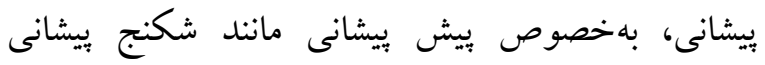
ميانى، فوقانى و تحتانى فعال شوند و همجيخين فعاليت هماهنكى را در قشر آهيانه به خصوص لوبول آهيانه

جدول r مشخصات مناطق فعال سازى براى شطرنج و استدلال منطقى

\begin{tabular}{|c|c|c|c|c|c|c|c|c|c|c|c|}
\hline \multicolumn{6}{|c|}{ مشخصات مناطق فعال سازى براى شطرنج } & \multicolumn{6}{|c|}{ مشخصات مناطق فعال سازى براى استدلال منطقى } \\
\hline $\mathbf{K}$ & $\mathbf{X}$ & $\mathbf{Y}$ & $\mathbf{Z}$ & نواحى مغزى & 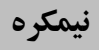 & $\mathbf{K}$ & $\mathbf{X}$ & $\mathbf{Y}$ & $\mathbf{Z}$ & نواحى مغزى & 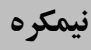 \\
\hline irrr & ir & 11 & ru & زير شكنج & جֶ & r999 & $-\mu F$ & -94 & $-\wedge$ & شكنج بس سرى ميانى & جֶب \\
\hline १९Y & rF & $-\wedge F$ & -1. & شكنج كمربندى & 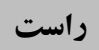 & 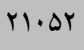 & $-\mu F$ & -94 & $-\wedge$ & مخحجه & جֶب \\
\hline arv & rF & $-\lambda F$ & -1. & 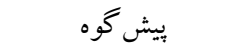 & 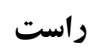 & $19 \cdot 19$ & $-r F$ & -94 & $-\wedge$ & مخججه & 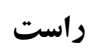 \\
\hline 949 & rF & $-\wedge f$ & -1. & آهيانه فوقانى & راست & $r \cdot r \Lambda$ & $-M F$ & -94 & $-\wedge$ & شكنج زبانى & جب \\
\hline 91. & YF & $-\wedge f$ & -1. & شكنج بس سرى ميانى & راست & 1111 & $-\mu F$ & $-9 r$ & $-\wedge$ & شكنجدو كى شكل & جֶب \\
\hline$\Delta \cdot v$ & YF & $-\lambda F$ & -1. & ي ״س سرى ميانى & راست & $\Delta \Delta I Y$ & $-M F$ & -94 & $-\wedge$ & زيرشكنج & جֶ \\
\hline mal & YF & $-\wedge F$ & -1. & دوكى شكل & جֶ! & r999 & $-M F$ & -94 & $-\wedge$ & شكنج بيشانى تحتانى & جֶب \\
\hline rAq & $-1 f$ & $-\lambda F$ & 94 & بيش گوه & جֶ & $9 F \Delta$ & $-M F$ & $-9 r$ & $-\wedge$ & اينسولا & جֶب \\
\hline VYI & rF & $-\wedge f$ & -1. & بِس سرى فوقانى & راست & rral & $-M F$ & $-9 r$ & $-\wedge$ & شكنج ييشانى فوقانى & جب \\
\hline YFG & rF & $-\wedge f$ & -1. & پِس سرى تحتانى & جٍ & MIFY & $-M F$ & $-9 r$ & $-\wedge$ & شكنج بيشانى ميانى & جب \\
\hline$r v$. & YF & $-\wedge F$ & -1. & لوبول آهيانه فوقانى & راست & 91 & $r$. & -9 & $\Delta 9$ & شكنج بيشانى تحتانى & جب \\
\hline rl. & YF & $-\wedge f$ & -1. & شكج دوكى شكل & جֶ & l.ru & $-M F$ & $-9 Y$ & $-\wedge$ & بيشانى فوقانى دوطرفه & راست \\
\hline $19 V$ & $-r q$ & $-r q$ & fr & شكنج ״س سرى تحتانى & جֶ & $11 r 9$ & $-M F$ & -94 & $-\wedge$ & بيشانى ميانى دوطرفه & راست \\
\hline V^ & YF & $-\lambda f$ & -1. & شكنج بـ بسى فوقانى & جِ & $1 \wedge 9$ & $-M F$ & -94 & $-\wedge$ & شكنج فوق حاشيهاى & راست \\
\hline $1 . r$ & rF & $-\wedge f$ & -1. & لوبول آهيانه تحتانى & جِ & $11 r$ & $-\mu F$ & $-9 r$ & $-\wedge$ & آهيانه تحتانى & جب \\
\hline v9 & YF & $-\wedge f$ & -1. & فوقحاشيهاى & راست & Irq. & $-M F$ & -94 & $-\wedge$ & لوبول آهيانه تحتانى & جب \\
\hline pVVr & rF & $-\wedge f$ & -1. & مخحجه & راست & vir & $-M F$ & $-9 r$ & $-\wedge$ & لويول آهيانه فوقانى & جب \\
\hline 1891 & YF & $-\lambda F$ & -1. & مخحِه & جֶ & IFF & $-M F$ & -94 & $-\wedge$ & آهيانه فوقانى & جִ \\
\hline r. & YF & $-\lambda F$ & -1. & شكنجزاويهاى & راست & rqV & $-\mu F$ & -94 & $-\wedge$ & شكنج ييشمركزى & راست \\
\hline$\Delta f$ & rf & $-\wedge f$ & -1. & شكنج بسمركزى & جِب & $\lambda \cdot r$ & $-\mu F$ & $-9 r$ & $-\wedge$ & شكنج كمربندى & جب \\
\hline$r \cdot \Lambda$ & YF & $-\lambda F$ & -1. & شكنج ييشانى تحتانى & راست & IVMA & Gr & f & $-\wedge$ & شكنج گيجكاهى ميانى & جب \\
\hline rVr & YF & $-\wedge f$ & -1. & شكنج بيشانى ميانى & جִب & IrAV & $-\mu F$ & -94 & $-\Lambda$ & ي يشانى تحتانى & جب \\
\hline ir & -09 & $-r$ & r & شكنج بيش مركزى & جب & $1 \cdot V \Delta$ & $-\mu F$ & $-9 r$ & $-\wedge$ & آهيانه تحتانى & جب \\
\hline ir & -19 & $-\wedge$ & 94 & شكنج ييشانى ميانى & راست & 1.11 & $-M F$ & -94 & $-\wedge$ & آهيانه فوقانى & جֶب \\
\hline 119 & $r$. & rq & 49 & شكنج بيشانى فوقانى & راست & $V F V$ & $-M F$ & -94 & $-\wedge$ & شكنج ״ِس سرى تحتانى & جִ \\
\hline ir & f & 9 & $r$. & شكنج كمربندى & جִ & $\Delta r v$ & $-r F$ & -94 & $-\wedge$ & شكنج يس مركزى & جب \\
\hline
\end{tabular}




\begin{tabular}{|c|c|c|c|c|c|c|c|c|c|c|c|}
\hline IAV & YF & $-\Lambda F$ & -1 & بِيشانى فوقانى دوطرفه & راست & $\Delta r$ & $-M F$ & $-9 r$ & $-\wedge$ & شكنج بيش مركزى & ֶֶ? \\
\hline \multirow[t]{10}{*}{ ir } & r. & YF & \&9 & بيشانى فوقانى دوطرفه & جִب & $r . q$ & $-M F$ & $-9 r$ & $-\wedge$ & شكنج گيجگاهى تحتانى & جֶֶ \\
\hline & & & & & & YAl & $-M F$ & $-9 r$ & $-\wedge$ & ت تالاموس & راست \\
\hline & & & & & & ro. & $-M F$ & $-9 Y$ & $-\wedge$ & كمربندقدامى & راست \\
\hline & & & & & & Frr & $-\mu F$ & $-9 r$ & $-\Lambda$ & آهيانه فوقانى & راست \\
\hline & & & & & & IFF & $-M F$ & $-9 r$ & $-\Lambda$ & شكنج بيشانى تحتانى & راست \\
\hline & & & & & & MFD & $-M F$ & $-M F$ & If & اينسولا & راست \\
\hline & & & & & & Ifrg & $-M F$ & $-9 r$ & $-\wedge$ & شكنج بيشانى ميانى & راست \\
\hline & & & & & & 99. & $-\mu F$ & -94 & $-\wedge$ & بيشانى فوقانى دوطرفه & راست \\
\hline & & & & & & INFV & $-\mu F$ & -94 & $-\wedge$ & ييش گوه & راست \\
\hline & & & & & & $\Delta I V$ & $-M F$ & $-9 r$ & $-\wedge$ & يِيش كوه & جِ \\
\hline
\end{tabular}

1، قسمت ه). در مورد بردازش دادههاى مربوط به تكليف استدلال منطقى نيز فعاليتهايى در مناطق بيشيشانى،

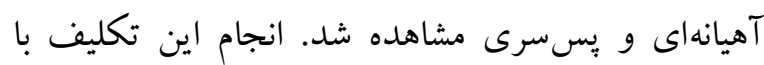
فعاليت قابل توجهى در مناطق مخجه دوطرفه، اينسولاى

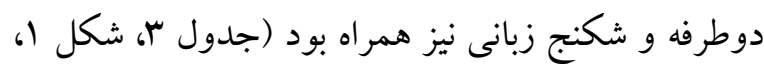

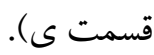

يردازش دادههاى مربوط به بازى شطرنج، فعاليت نواحى آهيانهاى به خصوص شكنج زاويهاى و لوبول آهيانه

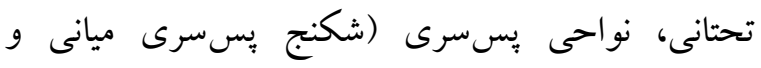

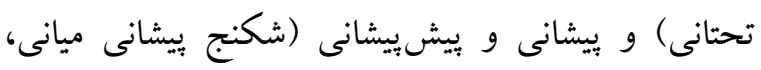

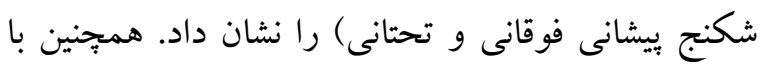
فعاليتى در مخجه دوطرفه نيز همراه بود (جدول سا، شكل

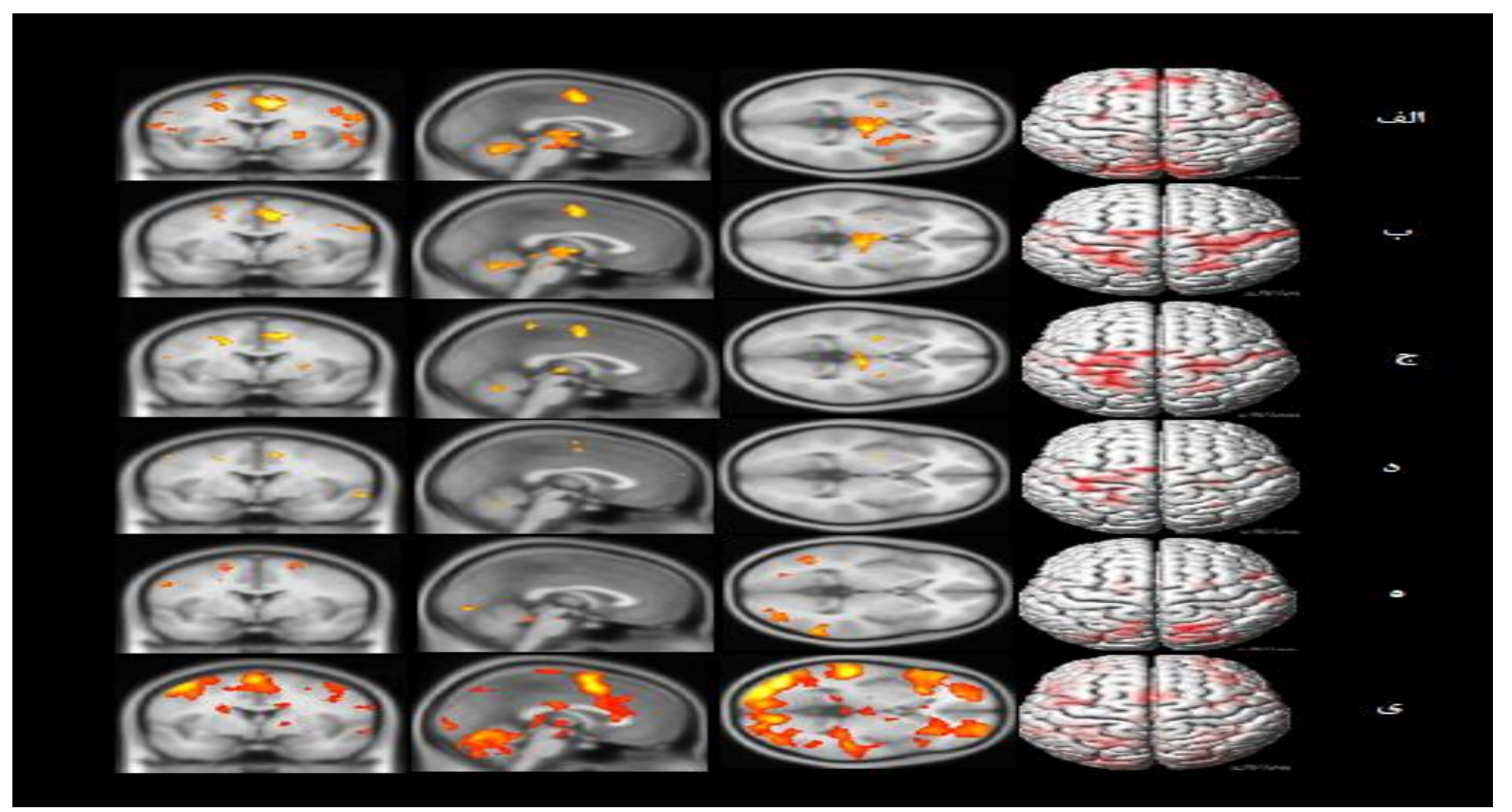

شكل ا نواحى فعالسازى مرتبط با جمع (الف)، تفريق (ب)، ضرب (ج)، تقسيم (د)، بازى شطرنج (ه) و استدلال منطقى (ى) 
همجِنين يافتهاى ما فعاليتى را در مناطق لوب يِيشانى نشان

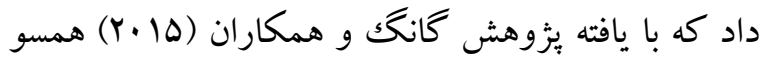

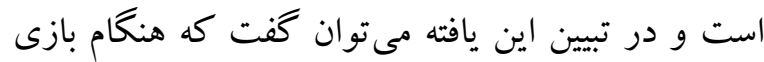
شطرنج، بهترين حركت از سوى بازيكن از طريق الكوهاى شطرنج، شبيهازى و تصور مىشود و بهوسيله درگير كردن عملكردهاى شناختى سطح بالا مانند برنامهريزى اقدامات آينده، دركك فضايى، حافظه فعال، حل مسئله، قضاوت و تصميم گيرى در مورد انتخاب الكوهاى قبلاً بدست آمده، به وجود مى آيد. در بايان طى تكليف استدلال منطقى دو ناحيه بزرگك در

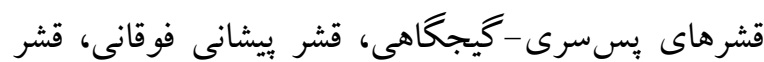
آهيانه تحتانى و فوقانى و قشر بيش بيشانى فعال شدند. اين

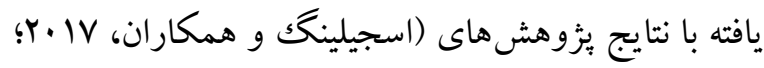

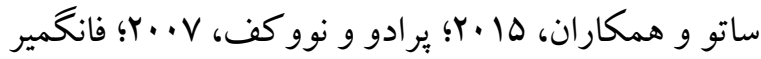

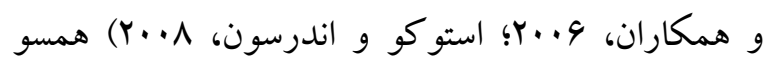
است. در تبيين يافتههاى بدست آمده مىتوان گفت فعال

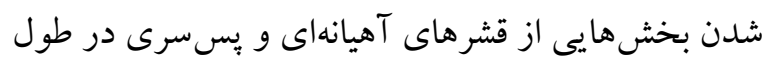
استدلال منطقى، به نقش فر آيندهاى بينايى - فضايى اشاره دارند و هر جه ويزگى هاى ديدارى بيشترى شرح داده شود، فعاليت بيشترى در مناطق بِسرى مشاهده مىشود

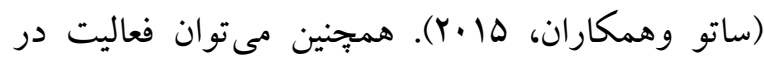
مناطق بيش ييشانى را به عنوان عملكرد شناختى سطح بالا

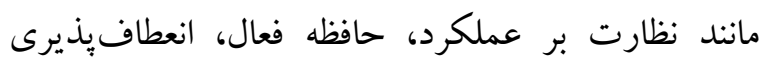
استراتزى و فر آيندهاى برنامهريزى بيان كرد (رزنبر گك،

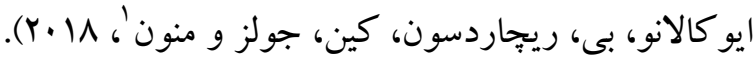
اين يافتها با نواحى ادعا شده توسط كاردنر در سال ب1919 مطابقت دارد؛ اما اين پيزوهش فعاليتهاى قابل توجهى را نيز در نواحى مخجه، اينسولا، شكنج

\footnotetext{
${ }^{1}$ - Rosenberg-Lee, Iuculano, Bae, Richardson, Qin, Jolles \& Menon
}

يثزوهش حاضر با هدف شناسايى مناطق فعالسازى مغزى مرتبط با هوش منطقى- رياضى براساس مهارتهاى اصلى اين هوش انجام شد. نتايج بدست آمده نشان داد كه هنگام انجام محاسبات فعاليت هماهنكى در قشر آهيانه و همجنين مناطق بيش بيشانى مانند شكنج بيشانى ميانى و فوقانى مشاهده مىشود. اين يافته با نتايج يثوهشهاى

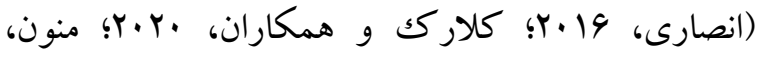

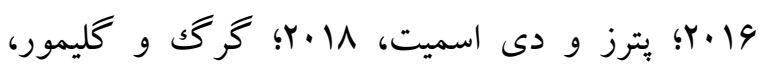

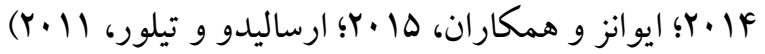
همسو است. در تبيين يافتهاى بدست آمده مى توان كفت مناطق آهيانه تحتانى و فوقانى دوطرفه كه مسئول دانش معنايى مقادير عددى هستند (ارساليدو و تيلور، (Y. Y)، ازجمله مناطق كليدى براى كارهاى محاسبه محسوب مىشوند و فعاليت بيشتر در لوبول آهيانه تحتانى، به عنوان شواهد عملكردى در مهارت بردازش مقدار عددى است و عمليات اعمال شده روى اعداد به حافظه كلامى و دستكارىهاى معنايى مرتبط با اندازه متكى است. همجنين فعاليت در لوب ويش بيشانى با عملكردهاى شناختى مانند حافظه فعال و تأكيد قابل توجه بر نقش آن در نظارت يا دستكارى اطلاعات كه در كارهاى محاسبه

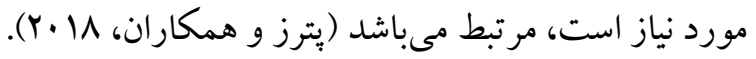
انجام بازى شطرنج نيز با درگيرشدن لوب هاى آهيانهاى و پِسرى همراه است. اين يافته نيز با بـزوهشهاى

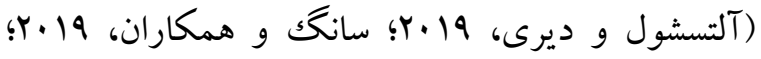

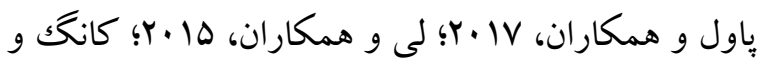
همكاران، ها ·r) همسو است. در تبيين اين يافته مىتوان كفت، اين مناطق با دركك فضايى، تصويربردارى و جرخش ذهنى درگير هستند (ياول و همكاران، IV) 


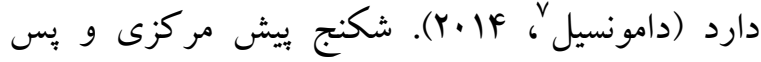
مركزى نيز با فعاليت قابل توجهى در اين تكاليف همراه بودند. در تبيين اين يافته مىتوان اشاره نمود كه شكنج بيش و پِّ مركزى در حركات جشم نقش دارند؛

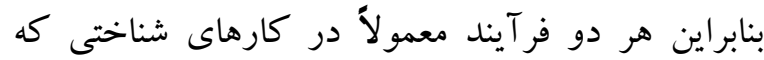
شامل ارائه محرككهاى ديدارى است، دخيل هستند. (اندرسون، مانان، حسين، رس، سامنر، بورت، مكك رابى و ولهرئ

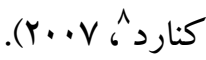

\section{نتيجه كيرى}

تفاسير بدست آمده از عصب شناختى هوش منطقى رياضى را مىتوان در تدريس و برنامهاى درسى استفاده كرده تا آموزش براساس شخصىسازى و نقاط قوت هر فرد بتواند، بيشرفت تحصيلى را بهبود بخشد و به عنوان يكك الكوى جامع در زمينهاى علوم اعصاب و همجينين مربيان به خدمت گرفته شود. اين مطالعه نيز مانند ساير مطالعات با محدوديتهايى همراه بود. براى مثال در مطالعات تصويرسازى تشديد مغناطيس كاركردى، تكاليف كار بايد تا حد امكان داراى محدوديت زمانى باشند. بدين معنا كه ارائه محركك بايد كوتاه و در حد جند ثانيه باشد؛ زيرا در فواصل طولانى كنترل فر آيندهاى مزاحم و نامربوط مانند سرگردانى ذهن دشوار مىشود. در بايان ذكر اين نكته مهم است كه طراحى تكاليف بهتر است به صورتى باشد كه نياز به باسخ دستى داشته باشد؛ زيرا ياسخهاى دستى بر ياسخهاى كلامى ترجيح دارند و سر با احتمال كمترى حركت مى كند و كيفيت تصاوير به خطر نمى افتد و اين خود محدوديت ديخرى براى استفاده

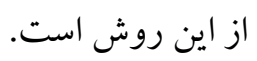

7. Dumontheil

8- Anderson, Mannan, Husain, Rees, Sumner, Mort, McRobbie \& Kennard

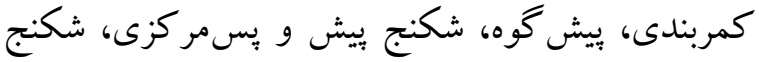
دوكى شكل و شكنج فوق حاشيهاى نشان مىدهد كه در هر سه مهارت جشمخير بودند. مخجه به دليل دخالت در عملكردهاى حركتى شناخته شده است و مطالعات صورت گرفته روى رياضيات، فعاليت مخجه را گزارش كردهاند (كلاركى، ليو، رايت،

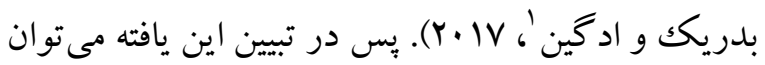

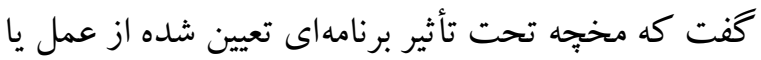
هدف تكليف، در هماهنگ ديدى ديدارى دخالت دارد. گوه بره مغز نيز با يردازش اطلاعات ديدارى مرتبط است (وانى،

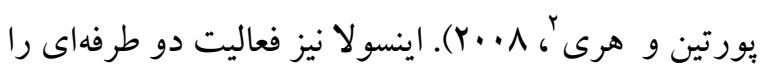
در حين انجام تكاليف نشان داد. اين يافته نيز با نتايج

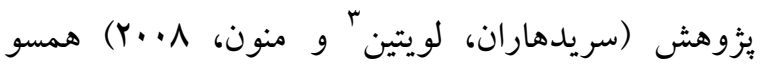
است. در تبيين يافته بدست آمده مىتوان كفت كه

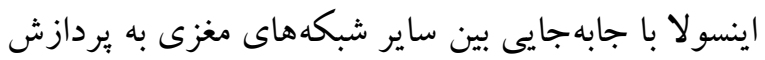

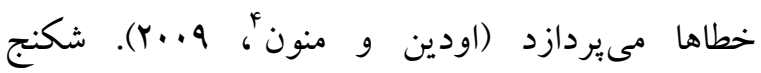
كمربندى نيز در يافتهاى بزّوهش جان و فردريكى

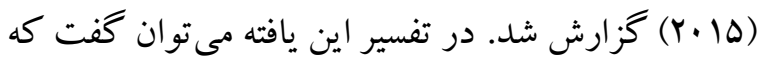

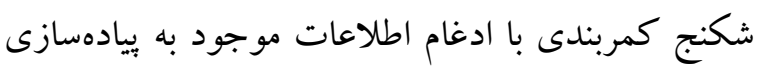
اهداف شناختى مى بردازد (جولز، سابيكار، ريجاردسون،

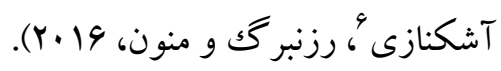
شكنج دوكىشكل به عنوان يكى ديخر از مناطق فعال شده در هوش منطقى - رياضى، در بزؤهش ارساليدو و

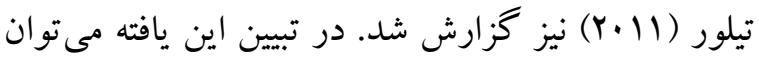
جنين عنوان نمود كه احتمالاً شكنج دوكى شكل نقش مؤثرى در تشخيص ديدارى محرك كها و تلفيق ويز گیىها

\footnotetext{
1. Clark, Liu, Wright, Bedrick \& Edgin

2. Vanni, Portin \& Hari

3. Sridharan \& Levitin

4 - Uddin \& Menon

5 - Jeon, \& Friederici

${ }^{6}$ - Jolles, Supekar, Richardson, Tenison \& Ashkenazi
} 
Clark CAC, Liu Y, Wright NLA, Bedrick A, Edgin JO. (2017). Functional neural bases of numerosity judgments in healthy adults born preterm. Brain and Cognition. 118, 90-99.

Cragg L, Gilmore C. (2014). Skills underlying mathematics: The role of executive function in the development of mathematics proficiency. Trends in Neuroscience and Education. 3, 63 68.

Dumontheil I. (2014). Development of abstract thinking during childhood and adolescence: The role of rostrolateral prefrontal cortex. Developmental Cognitive Neuroscience. 10,57-76.

Eggen P, Kauchak D. (2019). Educational Psychology. Translated by: Rashid KH. Tehran: Hoshmand Tadbir. 1, 194-198. (In Persian)

Evans TM, Kochalka J, Ngoon TJ, Wu SS, Qin S, Battista C, Menon V. (2015). Brain Structural Integrity and Intrinsic Functional Connectivity Forecast 6 Year Longitudinal Growth in Children's Numerical Abilities. Journal of Neuroscience. 35, 11743-11750.

Fangmeier T, Knauff M, Ruff CC, Sloutsky V. (2006). FMRI evidence for a three-stage model of deductive reasoning. J Cogn Neurosci. 18, 320-34.

Gong Y, Ericsson KA, Moxley JH. (2015). Recall of briefly presented chess positions and its relation to chess skill. PLoS One. 10, 35-55.

Jeon HA, Friederici AD. (2015). Degree of automaticity and the prefrontal cortex. Trends in Cognitive Sciences. 19, 244-250.

Jolles DD, Supekar KS, Richardson J, Tenison C, Ashkenazi S, Rosenberg-Lee M, Menon V. (2016). Reconfiguration of parietal circuits with cognitive tutoring in elementary school children. Cortex. 83, 231-245.

Li K, Jiang J, Qiu L, Yang X, Huang X, Lui S, Gong O. (2015). A multimodal MRI dataset of professional chess players. Scientific Data. 1, 44-53.

Menon V. (2016). Chapter 7 - Memory and cognitive control circuits in mathematical cognition an leaming. Prog Brain Res. 227, 159-86.

Peters L, De Smedt B. (2018). Arithmetic in the developing brain: A review of brain imaging

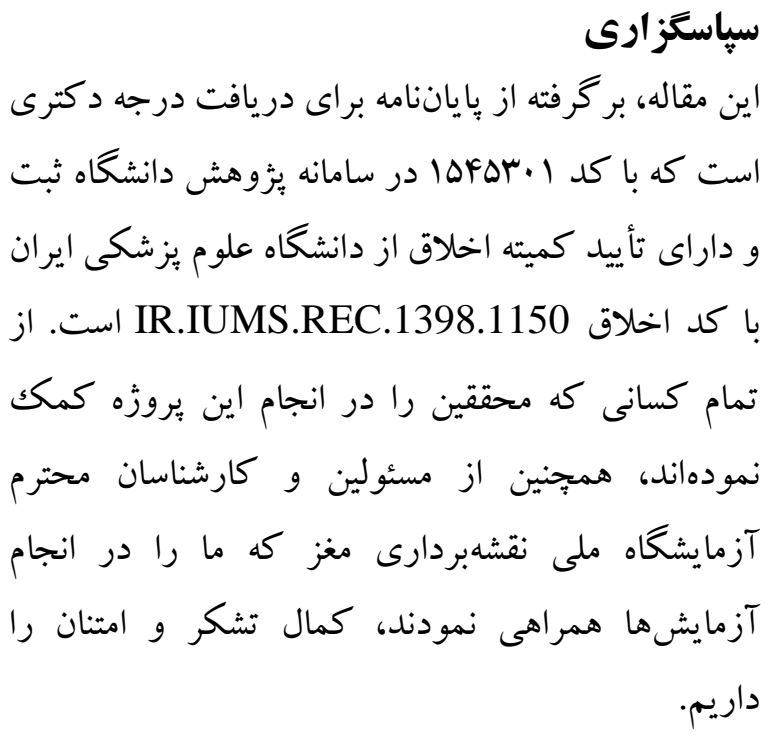

\section{References}

Altschul DM, Deary IJ. (2019). Playing analog games is associated with reduced declines in cognitive function: a 68 year longitudinal cohort study. $\mathrm{J}$ Gerontol B Psychol Sci Soc Sci. 75, 474-482.

Anderson EJ, Mannan SK, Husain M, Rees G, Sumne P, Mort DJ, McRobbie D, Kennard C. (2007). Involvement of prefrontal cortex in visual search. Exp. Brain Res. 180, 289-302.

Ansari D, Grabner RH, Koschutnig K, Reishofer G, Ebner F. (2011). Individual differences in mathematical competence modulate brain responses to arithmetic errors: An fMRI study. Learn Individ Differ. 21, 636-43.

Ansari D. (2016). Number Symbols in the Brain. Development of Mathematical Cognition: Neural Substrates and Genetic Influences. 2, 27-50. (InPersian)

Arsalidou M, Taylor MJ. (2011). Is 2+2=4? Metaanalyses of brain areas needed for numbers and 17 calculations. Neuroimage. 54, 238293.

Ashcraft MH. (1995). Cognitive psychology and simple arithmetic: A review and summary of new directions. J Numer Cogn. 1, 3-34.

Clark CAC, Hudnall RH, Perez-Gonzalez S. (2020). Children's neural responses to a novel mathematics concept. Trends Neurosci Educ. 20, 1-39. 
studies. Developmental Cognitive Neuroscience. 30, 265-279.

Powell JL, Grossi D, Corcoran R, Gobet F, Garcia Finana M. (2017). The neural correlates of theory of mind and their role during empathy and the game of chess: A functional magnetic resonance imaging study. Neurosci. 355, 149160.

Prado J, Noveck IA. (2007). Overcoming Perceptual Features in Logical Reasoning: A Parametric Functional Magnetic Resonance Imaging Study. J Cogn Neurosci. 19(4), 642-57.

Rosenberg-Lee M, luculano T, Bae SR, Richardson J, Qin S, Jolles D, Menon V. (2018). Short-term cognitive training recapitulates hippocampal functional changes associated with one year of longitudinal skill development. Trends in Neuroscience and Education. 10, 19-29.

Sato Y, Masuda S, Someya Y, Tsujii T, Watanabe S. (2015). An fMRI analysis of the efficacy of Euler diagrams in logical reasoning. VLHCC. $8,1-9$.

Schilling K, Gao Y, Janve Y, Stepniewska I, Landman BA, Anderson AW. (2017). Can increased spatial resolution solve the crossing fiber problem for diffusion MRI?. NMR in Biomedicine. 30, 87-101.

Shearer CB, Karanian JM. (2017). The Neuroscience of Intelligence: Empirical Support for the Theory of Multiple Intelligences? Trends Neurosci Educ. 6, 211-23.

Shearer CB. (2019). A detailed neuroscientific framework for the multiple intelligences: Describing the neural3components for specific skill units within each intelligence. Int $\mathbf{J}$ Psychol Stud. 11, 1-26.

Song L, Peng Q, Liu S, Wang J. (2019). Changed hub and functional connectivity patterns of the posterior fusiform gyrus in chess experts. Neurotherapeutics. 131, 74-86.

Sridharan D, Levitin DJ, Menon V. (2008). A critical role for the right fronto-insular cortex in switching between central-executive and default-mode networks. PNAS, 105, 12569 12574.
Stemberg RJ. (2018). The Nature of human intelligence. Cambridge University Press. 527-530.

Stocco A, Anderson GR. (2008). Endogenous Control and Task Representation: An fMRI Study in Algebraic Problem-solving. J Cogn Neurosci. 20, 1300-14.

Uddin LQ, Menon V. (2009). The anterior insula in autism: under-connected and under-examined. Neurosci. Biobehav. Rev, 33, 1198-1203.

Vanni S, Portin K, Hari R. (2008). Mu rhythm modulation during changes of visual percepts. Neurosci. 91, 21-31.

Waterhouse L. (2006). Multiple intelligences, the Mozart effect, and emotional intelligence: A critical review. Educational Psychologist. 41, 207-225. 